\title{
Geometric and poliorcetic inertia in the fortified system vs urban morphological inflections in 18th-Century. Barcelona
}

\author{
Juan Miguel Muñoz Corbalán \\ Departament d'Història de l'Art, Facultat de Geografia i Història, Universitat de Barcelona, Spain \\ E-mail: juanmiguelmunoz.corbalan@ub.edu
}

\begin{abstract}
Research Between the War of Nine Years and the Napoleonic invasion of 1808 Barcelona underwent a morphological transformation according to a progressive evolution that came along from a typical wall-constrained stronghold towards an urban structure where the primacy of the internal and external strategic control gave way to the socioeconomic, industrial and commercial detachment of the city. The warlike needs of the first quarter of the 18th century involved a series of explicit poliorcetic interventions that gradually made available other criteria related to the development of several infrastructures for peacetime and certain urban licenses. These improving processes that let transform the urban features later changed the sense of the vectors which settled the nexus between the intramural space and the territory beyond the bastioned perimeter. Starting from a predominantly centripetal structure where the city walls played a segregating role, they afterward tended to reinforce the creation of newborn civic spaces that appreciably reduced the strength of the suffocating perimeter and also established alternative centers of power. These procedures foreshadowed a further decline of the traditional values about the former city walls and allowed the take-off of the territory outside them as an expansion of the orthodox urban system essences and its outward projection. The confluence of both municipal government purposes and the Crown's impositions eased the work of the military engineers who undertook the interventions directly dependent on their sphere of responsibility.
\end{abstract}

Keywords: Military engineering, fortification, urban bastioned system, poliorcetics, city and territory.

\section{Introduction}

The urban global structure of Barcelona at the turn of the $17^{\text {th }}$ to the $18^{\text {th }}$ century, as so many other contemporary cities, was shaped mainly by its defensive needs. The continuous succession of warlike conflicts between several European monarchies forced the municipal authorities to restore the old urban walled system and prevent this way any siege attempt by an external army. This process constituted a permanent essay of adaptation and improvement to the poliorcetic characteristics of the city. But there was not enough money or time -nor even, maybe, the suitable technical skillfulness in terms of poliorcetics and fortification- to achieve the aim.

\section{Walls, towers and bastions before the Bourbons}

The city walls were the main defensive structure of Barcelona until the beginning of the $18^{\text {th }}$ century. A small fort near the bastion of Levante and the fortress of Montjuïc at the top of the hill complemented the whole system. However some sectors were not balanced, since several bulwarks had a poor poliorcetic capability and couldn't protect each other. 
When General Engineer Jorge Próspero Verboom was captured by the Austracists in the battle of Almenara in 1710 and transferred to Barcelona as a prisoner he had a precious opportunity to study all the city fortifications. He was able to analyze in detail the entire urban walled perimeter not only from the inside but also from the moat. All the data gathered by the Flemish engineer were decisive for the final victory of the Bourbon armies in the Siege of 1713-1714. He described accurately every part of the fortified system. From this exhaustive report he could assess all its poliorcetic strengths and weaknesses (Figure. 1).

Fortification implementations planned by French military engineers
On the occasion of the siege and seizure of the city on August 8, 1697 by the Duke of Vendôme in the context of the Nine Years' War between France and Spain, the French authorities confirmed the need to improve the status of the Barcelona defenses by establishing a powerful control towards the interior of the city, since they felt the possibility of any riot against the occupation forces. The geographer Nicolas de Fer showed in a map of Barcelona the urban poliorcetic system reformation plan by means of the transformation of the old arsenal (Atarazanas) into a kind of fortified redoubt facing both the western suburbs and the interior of the old city, taking advantage of the medieval wall of the Rambla as a former retrenchment. Similarly, the walled perimeter at the eastern

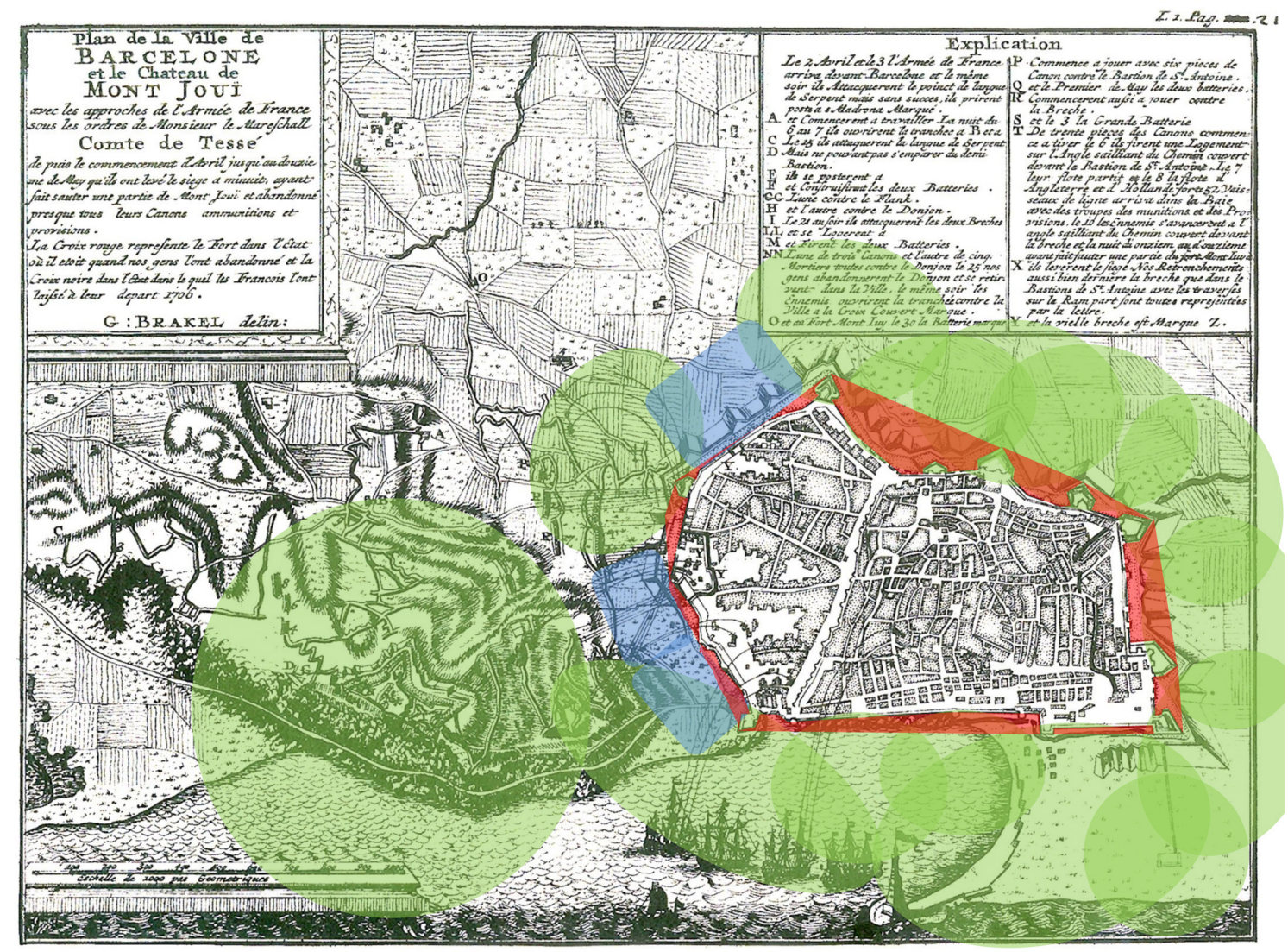

Figure 1. Brakel, G. (del.) 'Plan de la Ville de Barcelone et le Chateau de Mont Jouï avec les approches de l'Armée de France sous les ordres de Monsieur le Mareschall Comte de Tessé de puis le commencement d'Avril jusqu'au deuzieme de May (...) 1706'. Lamigue, Isaac (1715) Histoire du prince d'Orange et de Nassau (...) divisée en deux parties (...) Enrichie des Plans des villes, \& de leurs fortifications (Chez François Halma, imprimeur des Etats de la province de Frise, Lewarde). 2 vol. Grosso modo: in red, areas covered by each bastion flanking fire; in green, areas covered by each bastion global fire; in blue, fire from towers in the western side of the city. (Patterns and color by Muñoz Corbalán). 
part, between the bastion of Santa Clara and the Puerta de Mar, was supposed to be closed by a horn work with a crown structure, clearly offensive towards La Ribera, formerly the wealthiest and most dynamic urban district till the $16^{\text {th }}$ century. The increasing new constricted character of the city was still reinforced by the proposal of a four-bastion redoubt located on the slope of Montjuïc, between the castle itself at the top of the hill and its communication with the city. This comprehensive transformation of the Barcelona defenses, with the addition of several external fortification works and the erection of new bulwarks in the weakest points of the wall, implied a western extension of the harbor and the creation of a new arsenal or shipyard, covered by the fire of the abutting brand-new redoubt on the slope of Montjuic (fig. 2).
This poliorcetic concept was resumed by Paul-François de Lozières d'Astier in his project to fortify Barcelona after the surrender of the city on September 12, 1714, in competition with another one elaborated by the General Engineer of the Spanish Crown Jorge Próspero Verboom. The French engineer openly criticized the proposal made by the Flemish because of its supposed strategic inefficiency and he planned a system similar to the one conceived eighteen years earlier, when France and Spain were still enemies. Lozières took advantage of his active experience during the Barcelona sieges of 1697 and 1706. His thoughts were based around the supremacy of the castle of Montjuic, with the extension

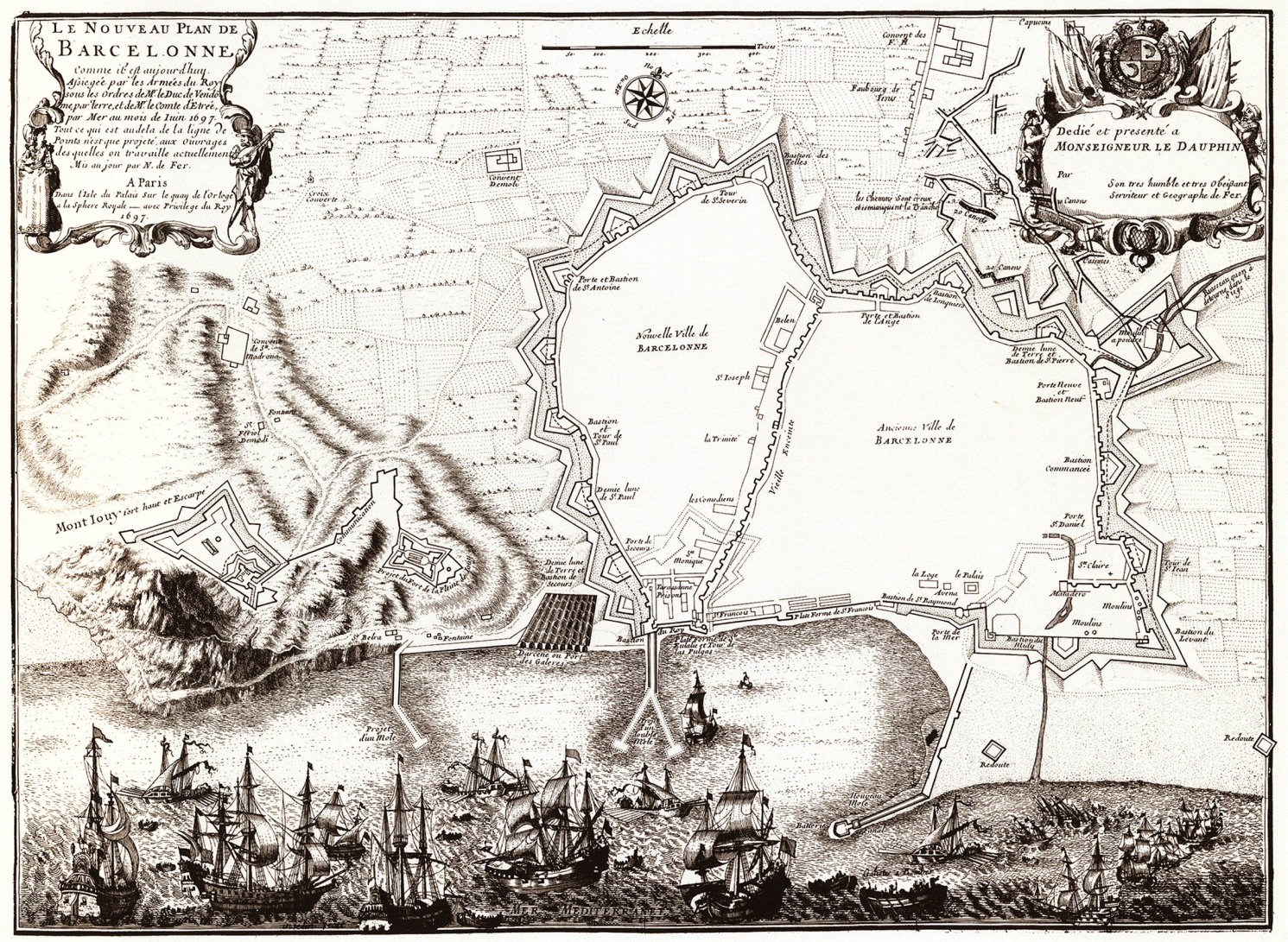

Figure 2. Fer, Nicolas de (del.), Inselin, Charles (fec.) (1697) 'Le Nouveau Plan de Barcelonne Comme il est aujourd'huy. Assiegée par les Armées du Roy sous les Ordres de Mr. Le Duc de Vendôme, par Terre, et de Mr. le Comte d'Etrée, par Mer au mois de Iuin 1697. Tout ce qui es audela de la ligne de Points n'est que projeté, aux ouvrages desquelles on travaille actuellement. Mis au jour par N. de Fer'. (Dans l'Isle du Palais sur le quay de l'Orloge a la Sphere Royale, Paris). 
of its offensive power over the city through a double horn work facing the city. In his Plan General de Barcelone he projected several complementary improving works for the urban wall, with the reinforcement of the bastion of the Ángel by means of a small doubled bastioned gorge threating the city, and a design not very far from what De Fer showed in 1697 with the projection of a sort of citadel-like triangular fortress, absolutely integrated in the area between the bastions of Santa Clara, Levante and Mediodía (Muñoz 1997).

\section{Walls, towers and bulwarks in a first peacetime under Phillipe V}

The project designed by Verboom consisted of a pentagonal bastioned citadel centered between the urban bulwarks of Santa Clara and Levante, which should disappear. The new fortress was complemented by the Fuerte Pío, a not far outer redoubt that faced the northern countryside, and the Fuerte Don Carlos, another one located on the beach line. In addition to restoring the wall ramparts and curtains, which were deteriorated by the bombing during the recent siege, the Flemish engineer organized an inner control belt with the transformation of a large part of the old Atarazanas into a pseudo-citadel, and also proposed to reconvert the bastion of Tallers in a kind of redoubtlike structure integrated in the city wall by means of a double exterior-interior function, both defensive and repressive, according to a poliorcetic morphology not very far from the one used several years ago, in 1701, when he himself designed the Fort Verboom, next to the Kieldrecht dike, a long strategical dam integrated in the Eastern Flanders Bedmarlinie, when the War of Succession to the Spanish Crown had not still left the Netherlands (Muñoz 2015a).

Barcelona was thus structured within a poliorcetic system where the walled perimeter strengthened its centripetal characteristics and consolidated a discrete defensive organization referred to the surrounding territory as well.

Some years later, in the mid-20s, a broad campaign ordered by the War Office tried to organize an effective network of quarters throughout the Kingdom in order to establish a permanent garrison in the major strategic strongholds and main border cities for the control of the territory. In the case of Barcelona, under the supervision of the Director Engineer of Catalonia Alejandro De Rez -Verboom's total confidence qualified professional since the campaigns in Flanders-, several buildings with different functions were reformed so as to be transformed into barracks for troops and officers (Muñoz 1994). Many of these soldiers had already been lodged in some interior places of the citadel, but the specific problematic of the city, because of the authorities' founded fear to any inner citizen rebellion, led to increase the number of troops in Barcelona. So it was necessary to turn some former buildings into military barracks to accommodate these contingents. The leading strategic concept kept being based, for several decades, on an idea of centripetal control over the urban space. Buildings such as the Atarazanas, the convents of San Agustín and Junqueras, the University (Estudi General) and the Lonja, all of them peripheral, very close to the urban walls and well located in places of strategic and significant balance for the city, were converted into military quarters with a striking regulatory character around their areas of influence. However it was not only important to achieve an inner control, but also to improve the external urban defensive system which was still incomplete.

When the duke of Montemar assumed the position of Secretary of War, he undertook intense enterprises related to the political structuring of the Kingdom in military terms. The Real Junta de Fortificaciones of Madrid became a new body of technical control of the Corps of Engineers. The wish to exercise a more rigorous and pragmatic supervision about the works planned and directed by the members of this group led to manage all the work that was intended to be materialized within the national territory. Montemar had got a special link with Barcelona, both institutional and emotional. There, he had been Captain General between 1722 and 1726 and had married two ladies of the local Catalan nobility. So he put a special attention in intervening on his beloved city. Some attempts were made to improve 
the urban fortifications. Several engineers designed a series of projects to consolidate one of the weakest parts of the walled perimeter, the front between the bastions of Tallers and Junqueras. In September 1737, Francisco Ricaud, Antonio Rivière, Baltasar Verboom, José Crane, Francisco de La Pierre and Antonio Fovet were asked to present some particular proposals to improve the defensive features of this city wall section by means of some exterior works and the addition of some integrated bulwark along the urban wall (Figure. 3). Formal solutions were, in some cases, the product of an excessive imagination, through which designers performed real exercises of typological variations from the conventional repertoire fixed by fortification treatises at the end of the $17^{\text {th }}$ century in different geopolitical contexts, mainly among French and Dutch theoreticians, but also throughout Sebastián Fernández de Medrano's lectures in the Royal Academy of Mathematics in Brussels and several of his books on poliorcetics and fortification. It's really interesting to realize how within the French post-vaubanian environment there was a similar process to the Barcelona bizarre example, in the sense that several engineers serving the French crown felt free to show out their creativity, elaborating complex systems which were supposed to improve the internationally recognized achievements made by Sébastien de Vauban both in projects and field works and also through many manuscripts and printed stuff summarized by other theoreticians and colleagues from the Corps $d u$ Génie. In fact, most of those poliorcetic dreams or academic graphic exercises were useless. They just constituted sophisticated ways of morphological stylization, and the more complicated they were, the more lack of functionality they had. At this point, it seems that technical mentality turned into an artistic delirium in a sort of anti-pragmatic mannerism, which created a true connection between art

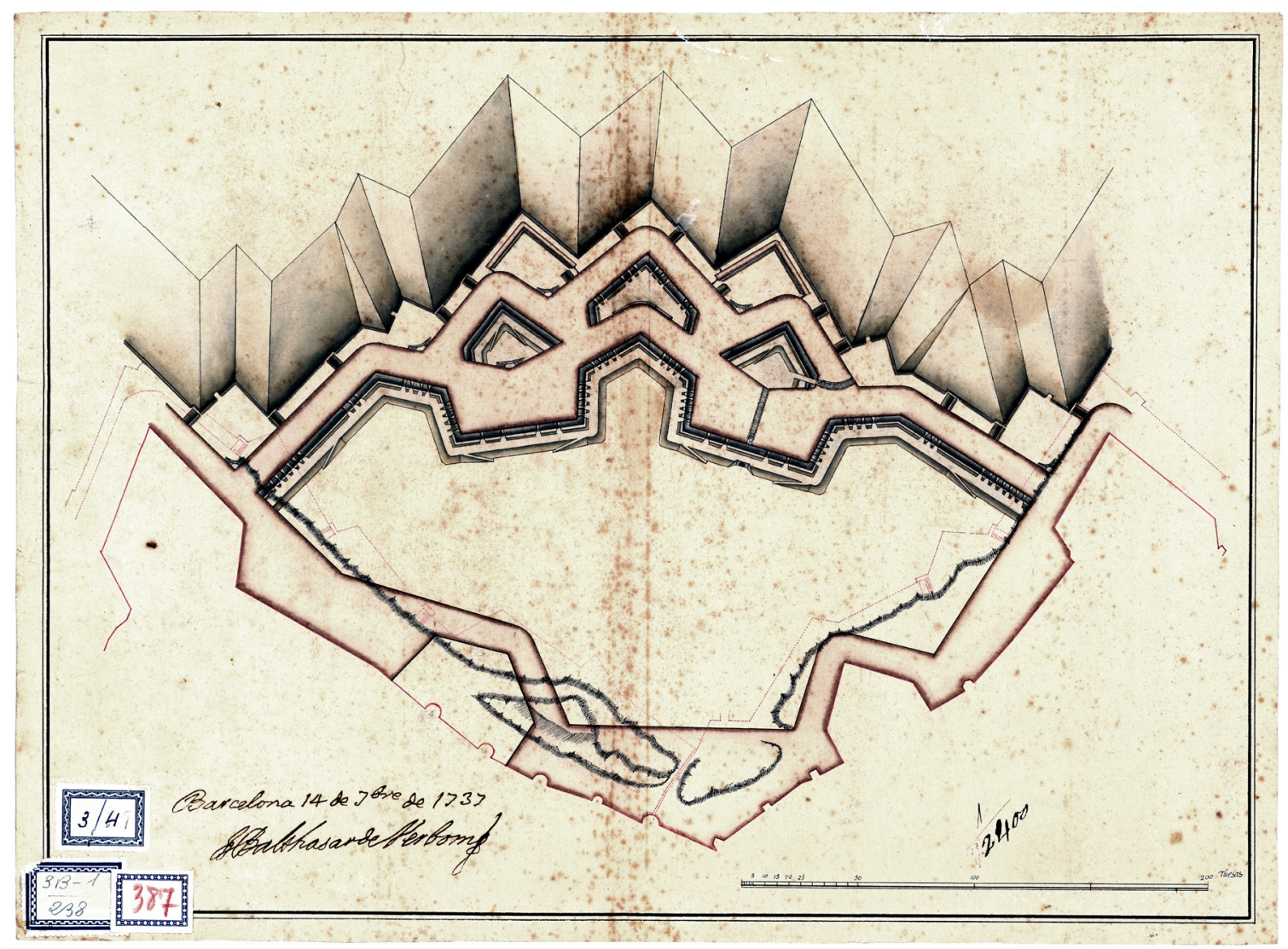

Figure 3. Verboom, Baltasar (1737) Project of fortification between the bastions of Tallers and Junqueras in Barcelona. Barcelona, September 14, 1737. Archivo General Militar, Madrid. Cartoteca Histórica, B-13/7. 
and technique (Muñoz 2015b). Some of the projects conceived by these French engineers were far both from the rational and logical postulates which were supposed to inspire all of them and their consequent strategic efficiency. However, their essential underlying theoretical arguments were meant to keep the balance between all inherent factors in any poliorcetic design so as to achieve the proposed objectives.

The intervention on the wall of Barcelona was intended to respect the poliorcetic orthodoxy, following the reasonable and commonly accepted fortification typologies and morphologies. The basic premise was to cover efficiently all the bastioned elements existing along the wall to prevent the presence of dead or passive zones. But the process was not imminent and it was necessary to wait for a new political context to decisively carry out such enterprises.

\section{A time for the city transformation under Ferdinand VI and Charles III}

The new policy developed by king Ferdinand VI and his War and Finances ministers allowed a change about the territorial strategic notion and the primacy of the monarchy defensive character. In strictly political terms, the engineers' commanders also echoed the deep reforms that the power wanted to carry out referring the Corps of Engineers and their functions and responsibilities. This new atmosphere revealed the institutional wish to encourage Spanish professionals -instead of the actual dependence on Flemish and French engineers- and modernizing their academic and technical training, as well as a greater rationalization and standardization of their skillfulness and procedures, despite the inevitable and usual lack of economic resources to undertake major initiatives (Cámara 2016).

As Juan Martín Zermeño and his son Pedro Martín Zermeño attained major responsibilities within the military engineers' organizational structure, their role in projecting large-scale enterprises became increasingly manifest. The father's career culminated when he got the General Command of the Corps and led some remarkable works in Catalonia such as the reformation project for the Barcelona fortified system in 1751, the design of the new outer Barceloneta neighborhood and the extraordinary fortress of San Fernando in Figueres, both in 1753 (Alfaro 2015).

In the case of Barcelona, the need to put into order its defensive system because of the latent threat of an enemy invasion opened the way not only to increase the suitability of the existing resources with the inclusion and modernization of specific elements but also the marginalization and even the elimination of some others which were considered obsolete and useless. Few years after the already planned reform of the walled front between the bastions of Tallers and Junqueras had been definitely undertaken -an intervention supervised by Pedro Martín Zermeño- this engineer elaborated a simple inquiry on the adjustments that should be made over the citadel's area of influence and the bastioned fortress itself. Throughout the short written explanation he expressed the idea of suppressing the Fuerte Pío, a strategic complement for the impressive pentagonal fortress and also a defensive advance of the city in the case of any attack coming from that northern zone of the countryside. However, this redoubt could become a hostile stronghold towards Barcelona itself and its citadel if taken by invading forces (Figure 4).

Along with the planning of the Barceloneta, this series of actions insinuated an incipient change in the defensive criterion applied to the city of Barcelona, which began gradually to be considered as an organic morphology whose projection outside the urban walls seemed to be absolutely inevitable. These novel ideas started to be reflected and applied during the third quarter of the century as regards the 'peaceful' and 'centrifuge' nature of the new planned interventions in the medium term. However, the authorities' concern about a possible public uprising encouraged the improvement of the internal control system, which was materialized with the reform and expansion of the urban military barracks network, the always intimidating presence of the citadel and the continuity of the repressive character of the bulwarks integrated in the walled perimeter.

Sixty years after the siege of Barcelona by the Bourbon armies, the former argument in 
order to establish a solid control of the city remained surprisingly valid. In fact, events like the Esquilache Riots in Madrid in 1766 -and its propagation by different cities of the Kingdom, among them Barcelona- contributed to keep this feeling alive. From the point of view of the impact on the urban form, the thoughts expressed in an anonymous document from 1774 emphasized not only the repressive character of the whole poliorcetic and military urban system, but its effect on some essentially civil elements as well1. The belt formed by the city walls, its towers and bastions was thus constituted by a poliorcetic-like circumvallation ring where the troops should "asegurar el recinto de la Plaza con tal arte (...) impidiendo el acceso del Paisanage al terraplén». Three were the main objectives: "guardar las Puertas con la maior firmeza», protecting them with paling or barrels «competentes à la defensa»; «impedir que los paisanos se apoderen de algún Baluarte, ò Cortina», trying to "cortar las avenidas al Muro por medio de Barreras» and controlling the guard-houses; and "que los Quarteles sean Yslados, retrincherados en lo interior de la Puerta, y coronados de Ladroneras» (Precauciones 1774, fol. 1r). These concepts, both generic in theory and strategic practice concerning any stronghold's internal security, were specifically detailed in each part of the technical analysis. The writer determined the need to reinforce the defensive belt safety by means of a greater isolation of the city wall since the smooth slope of the ramparts was an adverse factor to the restrictive power of the wall. His solution consisted in the erection of a parapet «de mamposteria hasta formar antepecho por todo el Recinto, capaz de contener las tierras, construiendo de distancia en distancia Garitas rectangulares interpoladas con las de la campaña», and eliminating «todas las casas y edificios unidos al terraplén», because they "son perniciosos padastros, que le importa al Muro desprenderse de ellos, sin que haya prerrogativa alguna, ò privilegio que pueda exceptuar à nadie, porque tienen la excelencia de encubrir à los paisanos que quieran atravesarle por debajo tierra para lograr su salida à la campaña por varias partes sin oposición alguna» (Precauciones 1774 , fol. $7 \mathrm{r}-7 \mathrm{v})$.
This dichotomy and greater segregation between the defenses and the urban structure itself was not in line with the evolution the city had been developing from some years ago. The repressive sense prevailed over other urban and civic considerations, since the argument about security was practically reduced to «impedir que los Paisanos, no solo salgan del cuerpo de la Plaza, pero ni aun se atrevan à arrimarse al terraplén» (Precauciones 1774, fol. 8v). In fact, one of the flourishing zones in terms of sociopolitical, economic and commercial leadership of Barcelona, Plaza de Palacio, was just contemplated under these strictly military criteria because it was "ordinariamente el parage donde se unen los principales seductores, y cabezas de motin para imponer leyes al General». The solution was to install a small armed redoubt on the "registro que se halla entre las dos Puertas [de Mar] (...) y con este preparativo queda limpia la Plaza al menor aviso» (Precauciones 1774, fol 6r-6v).

It is significant that, simultaneously with the need to maintain the effectiveness of the city's fortified defenses, the determined takeoff of Barcelona's economy and society since the mid-eighteenth century helped to generate a urban dynamic that allowed deep changes in the external road network (Figure. 5) and the transformation of certain centers of political and socioeconomic power, forming new spaces of urban hierarchy. Although the military points of reference continued to exercise a specific control over the social structure of Barcelona -throughout the dissuasive and factual presence of several military quarters strategically distributed all around the city, as well as the permanently visible and operative role of the fortified perimeter system-, the emergence of the civic world activated the raise of these non-military initiatives which undoubtedly accelerated the development of some infrastructures and other undertaken actions encouraged by the monarchy but also by the liberalization of various sectors of urban life (Història 1995).

In 1774 the Corps of Engineers was divided in three Branches (Strongholds and Fortifications, Academies of Mathematics, and Civil Architecture, Roads, Canals and Bridges). Together with the already consolidated 


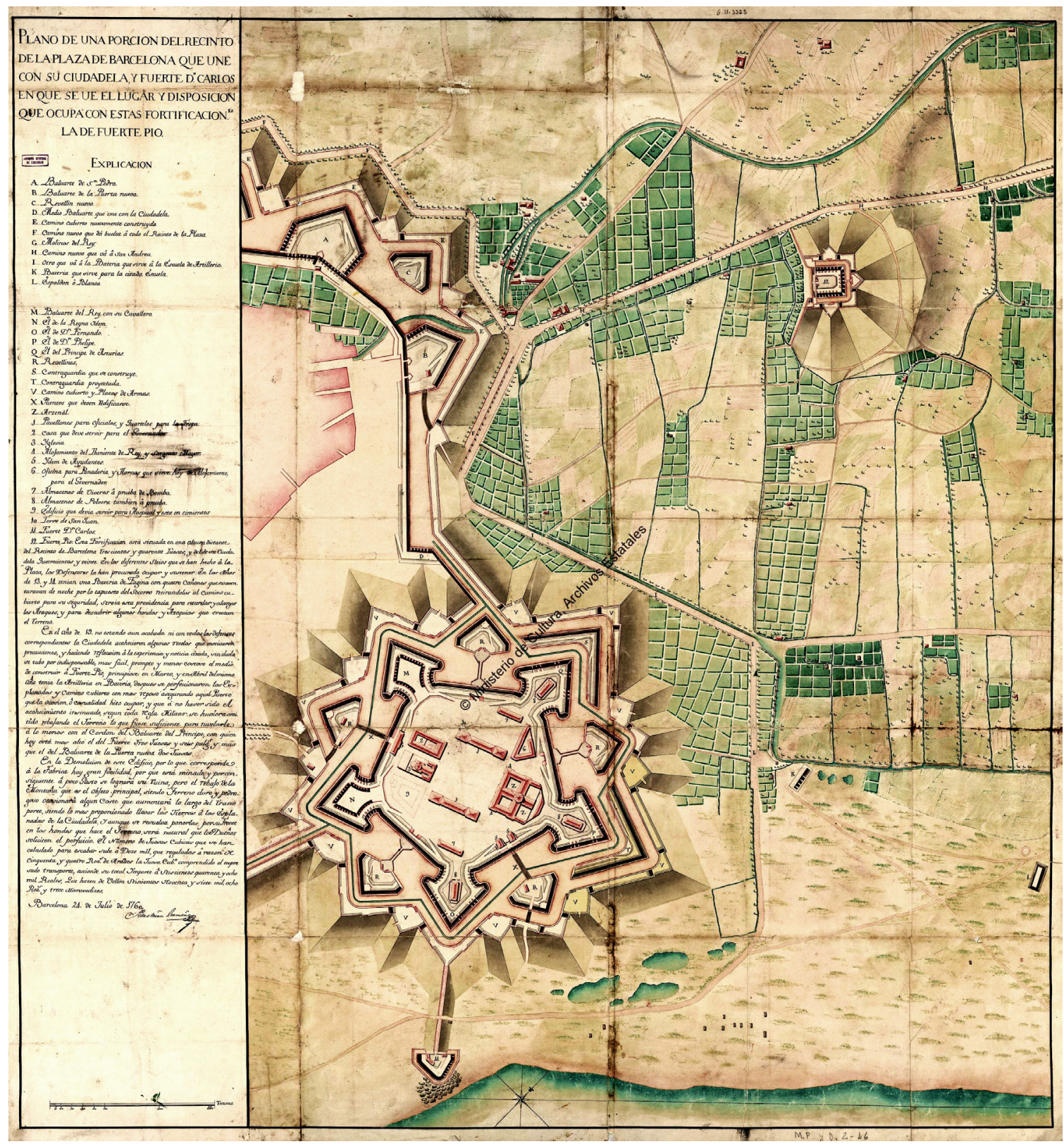

Figure 4. Zermeño, Pedro Martín (1760) 'Plano de una porción del recinto de la plaza de Barcelona que une con su ciudadela, y Fuerte D[0]n Carlos en que se ve el lugar y disposición que ocupa en estas fortificaciones la del Fuerte Pio'. Barcelona, July 24, 1760. Archivo General de Simancas. Mapas, Planos y Dibujos, 02, 046. 


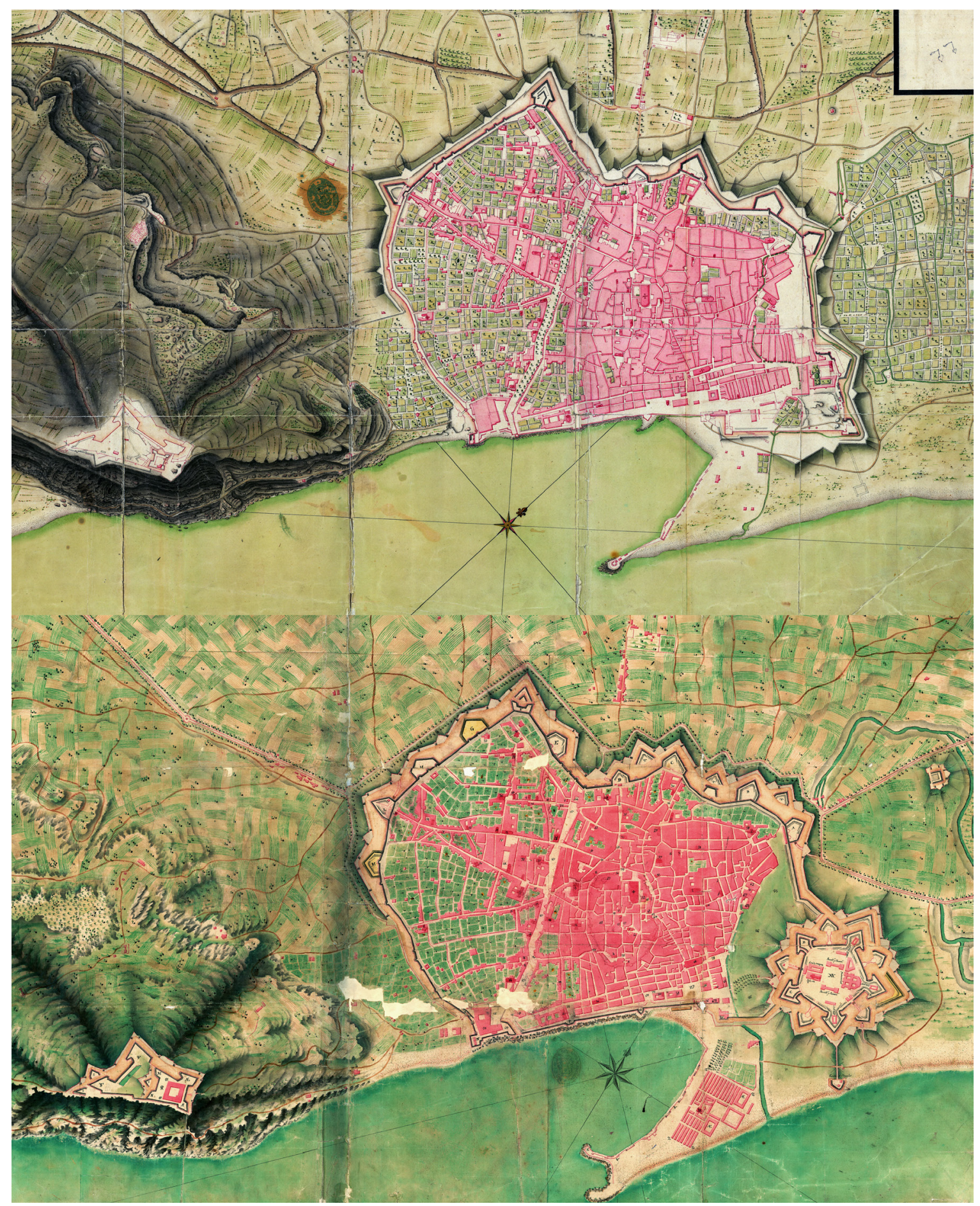

Up: Anonymous (ca 1695, copy) 'Plano de la Plaza de Barcelona' (detail). Archivo General Militar, Madrid. Cartoteca Histórica, B-36/18. Down: Anonymous (after 1773) 'Plano de la Plaza de Barcelona, Su Ciudad[el]a. Castillo de Mō[nt]jui[c] y Cercani[a]s' (detail). Archivo General Militar, Madrid. Cartoteca Histórica, B-36/17. 
power of the dictates coming from the Real Academia de las Tres Nobles Artes de San Fernando, officially founded in 1752, this new circumstances stimulated some building professionals who didn't belong to the military Corps to participate in non-strictly civil works traditionally undertaken by the monarchy under the responsibility of those military engineers.

\section{A further consideration for the new times under the reign of Charles IV}

In 1803 the military engineer Antonio López Sopeña, who was involved in a series of deep changes that affected the planimetric design of some of the most representative areas of the city, elaborated a comprehensive Descripcion de la Plaza de Barcelona. There, López Sopeña unveiled unambiguously the sociopolitical and economic transformations of the city and, therefore, how Barcelona should be adapted to this new reality2. The spirit that inspired this report proposed an urban and territorial analysis that went beyond the strictly military criteria usually being handled until a couple of decades ago. As a product of rigorous objectivity, López Sopeña summarily dissected the defensive structure of the city, understanding it as a system that integrated its own strategic essence into a higher-ranking body involving a living urban form and its territorial enclave.

Starting from the premise that the location of Barcelona on a plain -«elevándose este sobre las fortificaciones insensiblemente à poca distancia de las mismas, y siendo lleno de caminos hondos, acequias, y una inmensidad de Caserio, presentan à la vista un sin numero de obstáculos contra aquellas por proporcionar un comodo establecimiento al Enemigo que intente atacarlas» (Relacion 1803, fol. 2r)- was a great inconvenience for its effective protection, López Sopeña observed the urban defensive system formed basically by: seven bulwarks "por la parte de tierra» (two more under construction and some complementary exterior works); three bastions facing the harbor; the citadel; the Atarazanas, "cuyo puesto se puede considerar como una Ciudadela»; Fuerte Don Carlos, whose original purpose "fue el impedir la comunicación de la Barceloneta, y Marina con la campaña», Fuerte Pío, «expuesto à un golpe de mano, facilitando al sitiador un asilo fuerte desde el qual puede ofender à la Plaza, y cubrir el flanco de sus ataques»; the city gates with their corresponding guard-houses; seven intramural military quarters and two more in the Barceloneta; as well as thec of Montjuic, «la principal defensa que tiene la Plaza» (Relacion 1803, fol. 2v-8r).

It is interesting to observe how this brilliant engineer verified the coexistence of two technically anachronistic urban defensive typologies which, in fact, proved to be perfectly compatible and complementary, taking into account the double directionality of the external-interior poliorcetic character. When analyzing the outer perimeter of the city, he emphasized the complementarity between the medieval structure-«con torreones de bastante robustez»- and the modern works. About them, he pointed out that the bulwarks, since they were added "al muro antiguo, siendo más bajos que él, quedan cerrados por sus Golas con el referido muro proporcionándoles de este modo mayores defensas, por quedar construida una cortadura, que domina toda la extensión del Baluarte» (Relacion 1803, fol. 3r).

Another interesting aspect in López Sopeña's report is how he showed a change in the criteria when considering the strategic characteristics of a stronghold. The engineer highlighted the value of Barcelona's artificial harbor, one «de los de mayor concurso del Mediterráneo», which allowed him to derive his military dissertation towards the values of the city - «de las más importantes del Reyno»- as a center of territorial articulation in its both «maritima $y$ de tierra» condition and gifted with some relevant features in order to consolidate itself as the capital of commerce by means of issues such as «la industria de sus naturales, y el sin número de Fabricas de todas manufacturas que encierra», along with "la comodidad del Mar, y la fertilidad de su inmediata campaña» (Relacion 1803, fol. 8v).

This striking change of mentality, propitiated by the enlightened reformist policies developed during the last years of the reign of Carlos III -after the initiatives of the Count of 
Floridablanca- and their continuity during the first period of the reign of Charles IV, allowed opening new possibilities regarding the essential nature of the city. In Barcelona, such socio-economic rush was reflected in several interventions that affected the urban morphological and spatial reality (Figure. 6): the opening, enlargement, extension and urbanization of public streets and avenues such as La Rambla (A), Conde del Asalto (B), Calle Ancha (C) and Paseo de la Explanada (D) between the citadel and the district of $L a$ Ribera; the reform of the Lonja (E) and the consequent hierarchical ordering of the Plaza de Palacio $(F)$, with the erection of the new Customs $(G)$; the expansion of the Barceloneta neighborhood $(\mathrm{H})$, the harbor $(\mathrm{I})$, roads around the city and territorial communications $(\mathrm{J}) \ldots$ Antonio López Sopeña himself was responsible for designing and supervising several of the new military and public works in Barcelona, which were part of a general plan to modernize and 'civilize' a city whose morphology had been basically arranged for several centuries by strict strategic and poliorcetic factors.

\section{Methodology}

Most of the studies on Spanish military engineering during the $18^{\text {th }}$ Century are based on documentary manuscripts, graphic and cartographic material from several archives both civil like Archivo General de Simancas, Archivo General de Indias, Archivo de la Corona de Aragón, and military like Archivo General Militar, Centro Geográfico del Ejército. Other local archives offer some interesting data about municipalities and their relationship with the Crown enterprises. A special mention must be

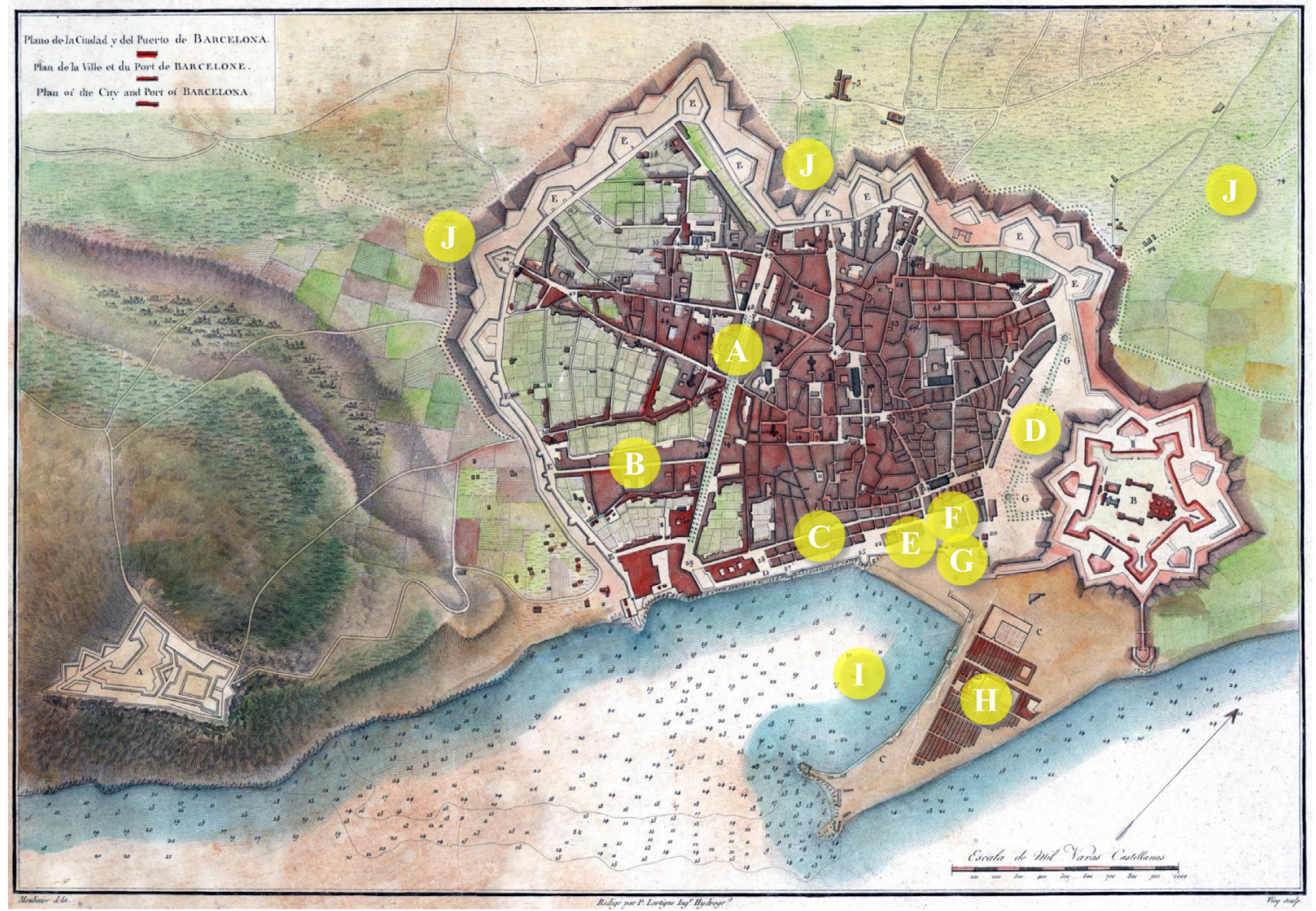

Figure 6. Manzano, Juan Serafín (1814) 'Plano y Vista de la Ciudad de Barcelona, y su puerto. Fue ocupada con engaño por las tropas del Tirano Napoleón Bounaparte, estando en Paz y unión con España, el día 12 de febrero del año de 1808 y permanecio bajo el Yugo de estos hasta el día 30 de Mayo del precente año de 1814 que fue entregada á las tropas Españolas' (detail). Archivo General Militar, Madrid. Cartoteca Histórica, B-36/20. (Highlighted reference numbers by Muñoz Corbalán). 
done on the information found in the French Archives de l'Inspection du Génie because of the continuous link between both monarchies. Contemporary treatises on military engineering and fortification are also a solid basis for the research.

\section{Conclusion}

Like most contemporary European cities, Barcelona's urban evolution during the $18^{\text {th }}$ century depended on its character as a constrained stronghold inside a walled perimeter. The city underwent several interventions which tried to increase both its defensive capacity towards the outside and its restrictive character concerning the urban interior.

Approaches used by military engineers in order to carry out the suggested projects respected many of the consolidated postulates used in treatises on poliorcetics and permanent fortification, both from the theoretical and practical point of view. However, the socioeconomic development run by Barcelona from the mid-eighteenth century helped to transform the closed and repressive vision of the city and gave way to a series of actions that changed the hierarchy of some centers of power and, consequently, the own urban form. It also allowed the contemplation of an incipient urban opening towards the surrounding space, both territorially and in its maritime projection3.

\section{Notes}

1 This text has been developed within the framework of the R \& D project "El dibujante ingeniero al servicio de la monarquía hispánica. Siglos XVI-XVIII. Ciudad e ingeniería en el Mediterráneo" (The draftsman engineer at the service of the Hispanic monarchy. 16th-18th centuries. City and engineering in the Mediterranean), ref. HAR2016-78098-P (AEI/ERDF, EU), funded by the Agencia Estatal de Investigación (Ministerio de Economía, Industria y Competitividad of the Spanish Government) and the European Regional
Development Fund (ERDF), of which I am a researcher.

2 Precauciones que convendria tomarse en el recinto de una Plaza [Barcelona] quando hay recelo evidente de infidelidad en los naturales, y que pueden ser corregidos con escarmiento si llegar à perder la obediencia al Rey. Anonymous, 1774. Archivo General Militar, Madrid. Catálogo General de Documentos, 3-2-10-4.

3 Relacion de la Plaza de Barcelona en que se manifiesta el actual estado de las obras de defensa, sus avenidas, y pahís que cubre, con otras circunstancias que se expresan. López Sopeña, Antonio. Barcelona, March 30, 1803. Archivo General Militar, Madrid. Catálogo General de Documentos, 3-2-1011.

4 This text becomes a first stage of several more specific investigations that, also integrated in the project HAR2016-78098-P, will deal with 'Los proyectos de mejora poliorcética de Barcelona durante el siglo XVIII entre la teoría y la fantasía' (Poliorcetic improvement projects for Barcelona during the 18th century between theory and fantasy) and 'La Aduana de Barcelona y la transformación del entorno urbanístico de la Plaza de Palacio a finales del siglo XVIII' (Barcelona Customs and the transformation of Plaza de Palacio's urban environment at the end of the 18th century).

\section{References}

Alfaro Gil, J. M. (2014) Juan Martín Zermeño. La ingeniería militar al servicio de la Ilustración (1713-1773) (Doctoral dissertation directed by Muñoz Corbalán, J. M.) (Universitat de Barcelona, Barcelona).

Cámara Muñoz, A. (2005) Los ingenieros militares de la monarquía hispánica en los siglos XVII y XVIII. (Centro de Estudios Europa Hispánica, Madrid).

Cámara Muñoz, A. (ed.) (2016) El dibujante ingeniero al servicio de la monarquía 
hispánica. Siglos XVI-XVIII (Fundación Juanelo Turriano, Madrid).

Capel, H., Sánchez, E. and Moncada, O. (1988) De Palas a Minerva. La formación científica y la estructura institucional de los ingenieros militares en el siglo XVIII. (El Serbal, Barcelona).

Cortada i Colomer, L. (1998) Estructures territorials, urbanisme i arquitectura poliorcètics a la Catalunya preindustrial. 2 vol. (Institut d'Estudis Catalans, Barcelona).

Fara, A. (1989) Il Sistema e la Città. Architettura fortificata dell'Europa moderna dai trattati alle realizzazioni 1464-1794 (Sagep, Genova).

Galera, M., Tarragó S. and Roca F. (1982) Atlas de Barcelona (Col·legi Oficial d'Arquitectes de Catalunya, Barcelona).

Gea, M. and Santanach, L. (2010) 'Poliorcètica defensiva: La ciutadella de Barcelona, contextualització i característiques bàsiques', Quaderns d'arqueologia i història de la ciutat de Barcelona. Quarhis. II, 6, 178-194.

Història. Política, Societad y Cultura dels Països Catalans, vol. 5 'Desfeta política y embranzida econòmica. Segle XVIII' (1995) (Enciclopèdia Catalana, Barcelona).

Lizaur y de Utrilla, A. (ed.) (2010) La ilustración en Cataluña. La obra de los ingenieros militares (Ministerio de Defensa, Madrid).

López, M. and Grau, R. (1971) 'Barcelona entre el urbanismo barroco y la revolución industrial', Cuadernos de arquitectura y urbanismo, 80, 28-40.

Montaner i Martorell, J.-M. (1990) La modernització de l'utillatge mental de l'arquitectura a Catalunya (1714-1859) (Institut d'Estudis Catalans, Barcelona).

Muñoz Corbalán, J. M. (1994) 'Los cuarteles de Barcelona durante el reinado de Felipe $\mathrm{V}$. Una responsabilidad constructiva compartida', Tiempo y espacio en el arte. Homenaje al Profesor Antonio Bonet Correa. 2 vol. (Editorial Complutense, Madrid), I, 707-732.

Muñoz Corbalán, J. M. (1997) 'El proyecto de fortificación para Barcelona en 1715 por Paul-François de Lozières d'Astier', El Mediterráneo: hechos de relevancia histórico-militar y sus repercusiones en España. V Jornadas Nacionales de Historia Militar. Sevilla, 9-12 de Mayo de 1995 (1997) (Universidad de Sevilla / Cátedra "General Castaños" - Región Militar Sur, Sevilla), 851-887.

Muñoz Corbalán, J. M. (2011) 'Cartografía militar y representación espacial de Barcelona en el siglo XVIII', Montaner, C. and Nadal, F. (ed.) (2011) Aproximacions a la història de la cartografia de Barcelona (Institut Cartogràfic de Catalunya and Arxiu Històric de la Ciutat de Barcelona, Barcelona), 31-45.

Muñoz Corbalán, J. M. (2015a) Jorge Próspero Verboom. Ingeniero militar flamenco de la monarquía hispánica (Fundación Juanelo Turriano, Madrid).

Muñoz Corbalán, J. M. (2015b) 'El dibujante ingeniero hacia la universalidad de la dualidad arte/técnica en la cartografía militar del siglo XVIII', Quintana, 14, 59-79.

Oliveras Samitier, J. (1998) Nuevas poblaciones en la España de la Ilustración (Fundación Caja de Arquitectos, Col. Arquithesis, 2, Barcelona).

Segovia Barrientos, F. and Nóvoa Rodríguez, M. (ed.) (2013) El arte abaluartado en Cataluña. Estrategia de defensa en el siglo XVIII (Ministerio de Defensa, Madrid). 